\title{
PEMERTAHANAN BAHASA BANJAR HULU DI KOTA BANJARMASIN PADA UMUR DEWASA (Ranah Keluarga, Pergaulan, Pekerjaan, dan Ranah Pendidikan)
}

\author{
Novia Winda dan Dana Aswadi \\ STKIP PGRI Banjarmasin \\ Email: noviawinda05@stikipbjm.ac.id
}

\begin{abstract}
Abstrak
Pemertahanan bahasa Banjar Hulu di Kota Banjarmasin merupakan sebuah fenomena perilaku bahasa yang menarik untuk dikaji dari perspektif sosiolinguitik. Penelitian ini bertujuan untuk:mendeskripsikan pemertahanan bahasa Banjar Hulu pada kelompok umur dewasa pada ranah keluarga, ranah pergaulan, ranah pekerjaan, ranah pendidikan. Responden yang terlibat dalam penelitian ini sebanyak 10 responden yang berdomisili di Kota Banjarmasin. Pengumpulan data dilakukan dengan cara penyebaran daftar pertanyaan, data tentang frekuensi penggunaan bahasa disajikan dalam bentuk tabel yang dianalisis secara kuantitatif. Penelitian ini menghasilkan temuan sebagai berikut.1) Pada ranah keluarga sebanyak $100,00 \%$ atau 10 responden kelompok dewasa masih menggunakan bahasa Banjar Hulu. 2) Ranah pergaulan persentase pemakaian bahasa Banjar Hulu pada kelompok dewasa adalah 90,00\% atau sebanyak 9 responden. 3) Pada ranah pekerjaan persentase pengunaan bahasa Banjar Hulu sebanyak 90,00\% atau sebanyak 9 responden. 4) Pada ranah pendidikan, dari 10 responden yang terlibat dalam penelitian ada 7 responden yang masih berstatus sebagai mahasiswa. Sebagian responden menggunakan bahasa Banjar Hulu dan penggunaan bahasa daerah lain juga menunjukkan jumlah yang sama dalam berkomunikasi. Sehingga dapat disimpukan pemertahanan bahasa Banjar Hulupada kelompok dewasa masih terlaksana di kotaBanjarmasin.
\end{abstract}

Kata Kunci: Bahasa Banjar Hulu, Pemertahanan Bahasa

\section{PENDAHULUAN}

Manusia dapat berkomunikasi dan berinteraksi dengan dengan menggunakan ekspresi verbal yang disebut bahasa. Bahasa merupakan alat komunikasi yang penting bagi manusia, dengan bahasa manusia dapat menyampaikan ide atau pikiran kepada orang lain. Bahasa tidak serta-merta hadir dengan sendirinya, ada pengaruh kultur dalam proses komunikasi tersebut. Bagaimana sebuah budaya menempatkan bahasa sebagai identitas serta nilai mutlak yang dimiliki oleh masyarakat.

Masyarakat Banjar Hulumerupakan masyarakat budaya yang memiliki kuantitas besar di Banjarmasin.Masyarakat ini menggunakan bahasa Banjar Hulu sebagai nilai identitasnya dalam kehidupan bermasyarakat dalam upaya pemenuhan kehidupan. Bahasa Banjar Hulu memiliki fungsi tersendiri sebagai identitas, antara lain: sebagai, (a) fungsi estetis (seperti kesenian) dan (b) fungsi praksis (bahasa sehari-hari), sehingga bahasa Banjar Hulu muncul sebagai aspek 
struktural yang wajib dipenuhi masyarakat Banjar Hulu secara internal, baik mencakup kebiasaan, adat, nilai, religi, dan bahasa itu sendiri.

Pergeseran bahasa dalam masyarakat menjadi sebuah ancaman bagi keberadaan bahasa Banjar Hulu sebagai identitas. Semakin banyaknya performansi individu, maka semakin rentan pula individu tersebut untuk tetap berkomunikasi dengan bahasa budaya asli, didukung pula oleh dominasi budaya yang lebih menitikberatkan pada bahasa secara universal bukan secara lokal. Pemertahanan bahasa, itulah yang harus dilakukan masyarakat agar identitas asli tetap terjaga.

Berdasarkan hal-hal di atas, peneliti tertarik untuk menelaah lebih jauh mengenai situasi kebahasaan di wilayah Banjarmasin terutama yang berkenaan dengan kemungkinan adanya pergesaran dan pemertahanan bahasa. Mengingat masyarakat Banjarmasin adalah komunitas yang plural. Komunitas di Banjarmasin tidak hanya didominasi oleh penduduk asli yang berbahasa Banjar Kuala, termasuk komunitas Banjar Hulu juga ada didalamnya.

Adapun masalah yang yang menjadi fokus dalam penelitian ini adalah sebagai berikut.

1. Bagaimana pemertahanan bahasa Banjar Hulu pada kelompok umur dewasa pada ranah keluarga?

2. Bagaimana pemertahanan bahasa Banjar Hulu pada kelompok umur dewasa pada ranah pergaulan?

3. Pemertahanan bahasa Banjar Hulu pada kelompok umur dewasa pada ranah pekerjaan?

4. Bagaimana pemertahanan bahasa Banjar Hulu pada kelompok umur dewasa pada ranah pendidikan?

Penelitian ini memiliki tujuan untuk mendeskripsikan hal-hal berikut ini.

1. Pemertahanan bahasa Banjar Hulu pada kelompok umur dewasa pada ranah keluarga.

2. Pemertahanan bahasa Banjar Hulu pada kelompok umur dewasa pada ranah pergaulan.

3. Pemertahanan bahasa Banjar Hulu pada kelompok umur dewasa pada ranah pekerjaan.

4. Pemertahanan bahasa Banjar Hulu pada kelompok umur dewasa pada ranah pendidikan.

\section{METODE}

\section{Pendekatan dan Jenis Penelitian}

Penelitian ini menggunakan pendekatan sosiolinguistik, yakni penelitian perihal kebahasaan di dalam kelompok sosial, yang dikaji adalah perilaku kelompok bukan perilaku perseorangan. Sosiolinguistik (Sumarsono, 2007 :6) mempelajari bahasa dalam hubungan dengan masyarakat, memiliki persamaan dengan sosiologi, sama-sama memerlukan data atau subjek lebih dari satu individu. Dalam kajian, keduanya menggunakan metode kuantitatif. Selanjutnya, dalam pengumpulan data digunakan metode survei, yakni metode penelitian untuk 
mengumpulkan dan menganalisis data sosial melalui daftar pertanyaan atau kuesioner yang sangat berstruktur dan rinci dengan tujuan memperoleh informasi dari sejumlah besar responden yang dianggap mewakili populasi.

Dalam penelitian pemertahanan bahasa ini variabel yang akan diteliti adalah penggunaan bahasa, untuk penggunaan bahasa responden menggunakan beberapa variabel yakni variabel bebas dan variabel terikat, dan yang menjadi perhatian adalah ranah penggunaan bahasa dan mitra bicara (interlokutor), semuanya dalam bentuk hubungan-peran, lokasi, dan peristiwa bahasa yang sesuai untuk keperluan penelitian pola penggunaan bahasa. Dengan demikian, penelitian ini mengungkapkan bagaimana hubungan dua variabel, yakni variabel ranah penggunaan bahasa Banjar Hulu dan variabel yang diduga berpengaruh terhadap ranah penggunaan Banjar Hulu, yakni faktor usia, pekerjaan, pendidikan, jenis kelamin, agama, loyalitas bahasa dan tempat lahir. Variabel usia, pekerjaan, pendidikan, jenis kelamin, agama, loyalitas bahasa, dan tempat lahir merupakan variabel bebas dan penggunaan bahasa Banjar Hulu dalam ranah kekeluargaan, ranah pergaulan, ranah pekerjaan, dan ranah pendidikan sebagai variabel terikat.

Adapun variabel bebas dan variabel terikat dalam penelitian ini dapat digambarkan seperti terdapat dalam diagram berikut.

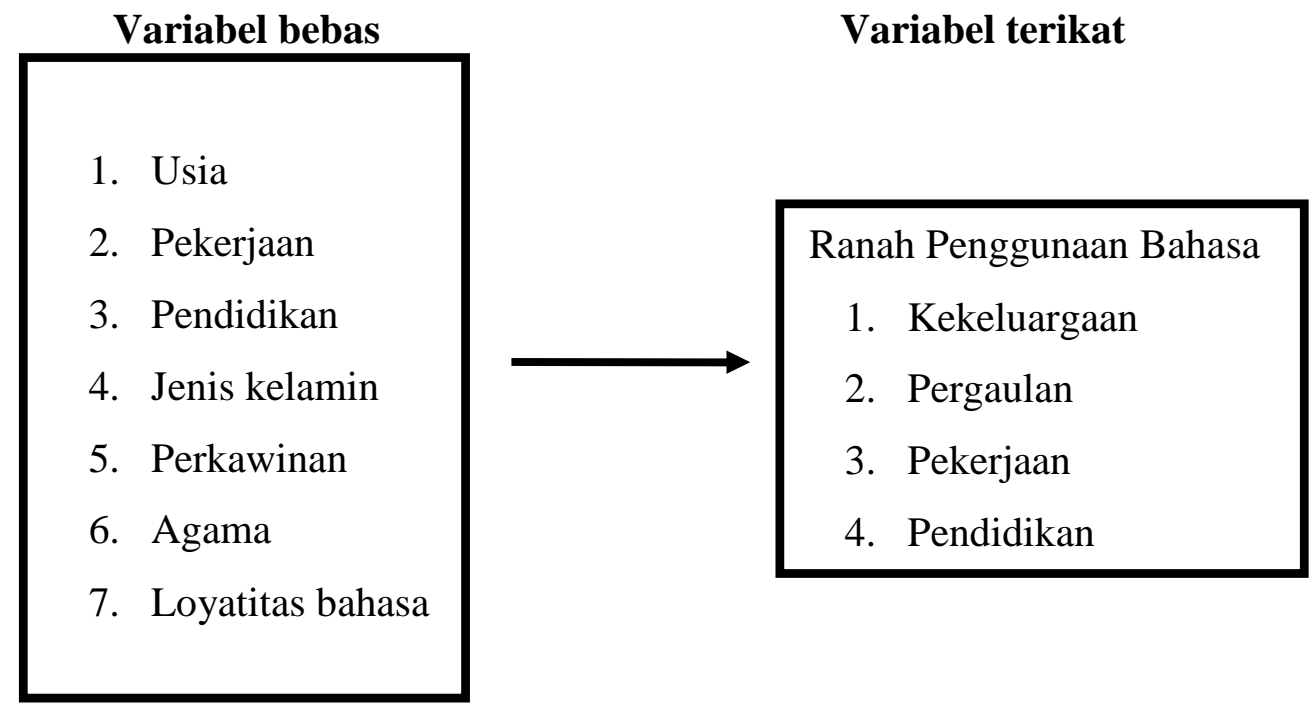

\section{Populasi dan Sampel}

Populasi penelitian ini adalah masyarakat bahasa Banjar Hulu yang berdomisili di wilayah Banjarmasin, yakni di Komplek H. Iyus Kelurahan Surgi Mufti Kotamadya Banjarmasin sebagai sumber penelitian.Sesuai dengan tujuan yang hendak dicapai dalam penelitian ini, yakni untuk mengetahui tingkat pemertahanan bahasa banjar Hulu di Banjarmasin. Berkaitan dengan itu, karena keterbatasan waktu penelitian maka populasi penelitian ini hanya mengambil beberapa pemercontoh (sample) sebagian objek yang diteliti atau hanya meneliti elemen sampel bukan seluruh elemen populasi.

Sejalan dengan itu, Milroy dalam Gunarwan (2002: 46), mengatakan bahwa untuk penelitian kebahasaan, pemercontoh yang besar cenderung tidak 
perlu. Hal ini karena perilaku linguistik itu lebih homogen daripada perilaku lain. Walaupun demikian, pemercontoh dalam penelitian ini tetap menggunakan desain pemercontoh yang lazim dalam penelitian pada umumnya, yakni menentukan pemercontoh dengan cara acak-berlapis. Jumlah pemercontoh ditetapkan sepuluh responden dari populasi dewasa, yakni terdiri atas lima laki-laki dan lima perempuan.

Pemilihan responden juga dilakukan berdasarkan syarat-syarat penentuan responden yang memenuhi syarat. Adapun responden yang dipakai dalam penelitian ini adalah dengan kriteria sebagai berikut:1)penutur asli bahasa Banjar Hulu berusia 21 sampai dengan 40 tahun yang tinggal diwilayah Banjarmasin,2)berdomisili di Banjarmasin, 3) minimal berpendidikan SD,4)dapat berbahasa Indonesia,5) sehat dan tidak mempunyai cacat wicara,6)bersedia menjadi responden, dan 7) teliti, cermat, dan mempunyai daya ingat yang baik.

\section{Prosedur Pengumpulan Data}

Teknik yang digunakan, yakni teknik kuesioner survei dengan menggunakan pertanyaan-pertanyaan semi terbuka (masih ada kemungkinan jawaban tambahan). Kuesioner (daftar pertanyaan) yang dibagikan berisi pertanyaan yang telah disusun terlebih dahulu berdasarkan masalah dan tujuan yang akan dicapai dalam penelitian ini. Daftar pertanyaan itu kemudian dibagikan kepada responden. Responden mengisi kuesioner tanpa menyebut nama dengan harapan responden bersifat jujur, terbuka, tidak ragu, dan tidak merasa takut mengisi dan menjawab pertanyaan-pertanyaan dalam kuesioner itu. Kuesioner yang telah diisi responden menjadi data dan siap untuk diolah (Astar dkk, 2003) dan data yang didapatkan dianalisis secara kuantitatif.

\section{Analisis Data}

Data yang didapatkan kemudian dianalisis dengan cara penghitungan persentase mengikuti pola perhitungan Muhajir dalam Damanik (2009: 17), yaitu perhitungan yang didasarkan pada jumlah jawaban yang masuk. Pertimbangannya adalah bahwa setiap pertanyaan mungkin tidak akan dijawab oleh responden. Angka persentase akan disajikan dalam dua angka dibelakang koma.

Data dalam penelitian ini akan disusun dalam bentuk tabel. Penyusunan dalam bentuk tabel atau tabulasi ini merupakan tahap lanjutan dalam rangkaian proses analisis data (Koentjaraningrat, 1993). Data yang telah masuk mula-mula dicatat, lalu disesuaikan dengan pengelompokan yang telah dilakukan kemudian ditarik dalam angka-angka gabungan yang dipakai sebagai dasar analisis. Dari hasil pengolahan data tersebut akan terlihat kecenderungan-kecenderungan tertentu yang kemudian dimasukkan ke dalam tabel-tabel tabulasi dan grafik. Hasil tabulasi faktor-faktor identitas sosial seperti kesukuan, umur, jenis kelamin, tingkat pendidikan dan latar belakang sosial ekonomi responden.

Berkaitan dengan skala pengukuran dalam menganalisis data dalam penelitian ini digunakan skala pengukuran nominal, ordinal, interval, dan rasio (Nasution dalam Damanik (2009: 30)). Dalam hal ini, skala nominal merupakan 
sebatas label yang diberikan terhadap kategori jenis kelamin, usia, status keluarga, pekerjaan, pendidikan, tempat lahir, identitas responden, lama tinggal, status suku. Sementara itu, skala ordinal dalam penelitian ini mengandung pengertian tingkatan, yakni yang berkaitan dengan kelompok usia responden. Selanjutnya, skala interval dalam penelitian ini merupakan klasifikasi secara kuantitatif dari objek penelitian, dalam hal ini peneliti hendak meneliti apakah bahasa Bakumpai itu masih bertahan atau tidak bertahan. Adapun setiap pertanyaan (indikator) yang terdapat dalam kuesioner yang diberikan kepada responden dijawab dengan menggunakan pilihan jawaban: Responden masih menggunakan bahasa 1. Bahasa Banjar Hulu, 2. Bahasa daerah lainnya, 3. Bahasa Indonesia. Kemudian dibuatlah standar penilaian dalam bentuk interval, yaitu:

1) Jika jawaban responden menggunakan bahasa Banjar Hulu persentasinya 51\%--100\% dianggap bahwa Banjar Hulu masih bertahan.

2) Jika jawaban responden menggunakan bahasa Banjar Hulu persentasi 0\%--50\% bahasa Banjar Hulu dianggap tidak bertahan.

Untuk lebih rincinya, dalam menghitung bertahan atau tidaknya bahasa Banjar Hulu di Banjarmasin digunakan dengan cara menghitung nilai tengah atau median, yakni dihitung dari setengah jumlah responden. Nilai tertinggi dihitung dari nilai tengah ke atas dan nilai terendah dihitung dari nilai tengah ke nilai terbawah. Misalnya, jumlah responden ada $10(100,00 \%)$ maka rumus yang digunakan adalah $10(100,00 \%): 2=5(50,00 \%)$, maka jumlah responden $0-5$ atau $<50,00 \%$ berarti bahasa Banjar Hulu tidak bertahan, sedangkan jumlah responden $6-10$ atau $>50,00 \%$ bermakna bahasa Banjar Hulu masih bertahan.

\section{HASIL DAN PEMBAHASAN \\ Identitas Sosial Responden}

Jumlah responden pada penelitian ini adalah 10 orang responden dewasa yang terdiri dari 5 responden laki-laki dan 5 responden perempuan. Jawaban yang diperoleh pada tabel di bawah ini merupakan jawaban atas pertanyaan untuk menentukan jenis kelamin responden.

Tabel 1.

Jumlah responden menurut jenis kelamin $(\mathrm{N}=10)$

\begin{tabular}{|c|c|c|c|}
\hline No & Jenis Kelamin & f & $\%$ \\
\hline 1 & Laki-laki & 5 & $50,00 \%$ \\
\hline 2 & Perempuan & 5 & $50,00 \%$ \\
\hline & Jumlah & 10 & $100,00 \%$ \\
\hline
\end{tabular}

Data yang diperoleh dari hasil penyebaran angket untuk tiga kelompok responden ini meliputi usia, pendidikan, pekerjaan, tempat lahir. Selanjutnya, tabel 2 di bawah ini menggambarkan usia responden, data diperoleh atas pertanyaan.

Berapakah usia Anda saat ini?

Tabel 2.

usia responden $(\mathrm{N}=10)$ 


\begin{tabular}{|c|c|c|c|}
\hline No & Usia & $\mathrm{F}$ & $\%$ \\
\hline 1 & $<20$ & 0 & $0,00 \%$ \\
\hline 2 & $21-40$ & 10 & $100,00 \%$ \\
\hline 3 & $>41$ & 0 & $0,00 \%$ \\
\hline & Jumlah & 10 & $100,00 \%$ \\
\hline
\end{tabular}

Pekerjaan sebagai variabel penelitian ini dibagi menjadi 4 kelompok, yaitu pegawai negeri, wiraswasta, petani, dan lainnya. Dari hasil penyebaran kuesioner didapat hasil bahwa dari 10 responden2 responden $(20,00 \%)$ bekerja sebagai wiraswasta, 1 responden $(10,00 \%)$ absen, dan 7 responden $(11,66 \%)$ bekerja lainnya (mahasiswa). Untuk memperoleh data mengenai pekerjaan responden dapat dilihat pada tabel 3 di bawah ini.

Tabel 3.

Pekerjaan responden $(\mathrm{N}=10)$

\begin{tabular}{|c|l|c|c|}
\hline No & \multicolumn{1}{|c|}{ Pekerjaan } & f & $\%$ \\
\hline 1 & Pegawai Negeri & 0 & $00,00 \%$ \\
\hline 2 & Wiraswasta & 2 & $20,00 \%$ \\
\hline 3 & Lain-lain (mahasiswa) & 7 & $70,00 \%$ \\
\hline 4 & Blangko & 1 & $10,00 \%$ \\
\hline & Jumlah & 10 & $100,00 \%$ \\
\hline
\end{tabular}

Variabel pendidikan dibagi menjadi 4, yaitu Sekolah Dasar (SD), Sekolah Menengah Pertama (SMP), Sekolah Menengah Atas (SMA), dan Akademi/Perguruan Tinggi (PT). Dari hasil penyebaran kuesioner didapat hasil bahwa dari 10 responden sebanyak 5 responden tamat di akademi/perguruan tinggi dan 5 responden tamat SMA.

Jawaban yang disajikan dalam tabel 4 di bawah ini merupakan jawaban atas pertanyaan

\section{Pendidikan tertinggi Anda?}

Tabel 4.

Pendidikan responden $(\mathrm{N}=10)$

\begin{tabular}{|c|l|c|c|}
\hline No & \multicolumn{1}{|c|}{ Pendidikan } & F & $\%$ \\
\hline 1 & Akademi/ Perguruan Tinggi & 5 & $50,00 \%$ \\
\hline 2 & SMA & 5 & $50,00 \%$ \\
\hline 3 & SMP & 0 & $0,00 \%$ \\
\hline 4 & SD & 0 & $0,00 \%$ \\
\hline & Jumlah & 10 & $100,00 \%$ \\
\hline
\end{tabular}

Berdasarkan status perkawinan responden pada penelitian ini dikelompokkan atas dua status, yakni responden yang sudah kawin dan yang belum kawin. Pertanyaan yang diajukan untuk memperoleh jawaban pada tabel di bawah ini adalah.

$$
\text { Apakah Anda sudah berkeluarga? }
$$

Tabel 5.

Perkawinan responden $(\mathrm{N}=10)$ 


\begin{tabular}{|c|l|c|c|}
\hline No & \multicolumn{1}{|c|}{ Perkawinan } & F & $\%$ \\
\hline 1 & Kawin & 1 & $10,00 \%$ \\
\hline 2 & Belum kawin & 9 & $90,00 \%$ \\
\hline & Jumlah & 10 & $100,00 \%$ \\
\hline
\end{tabular}

Hasil yang didapat dari penyebaran kuesioner sebanyak 1 responden $(10,00 \%)$ mengaku sudah berkeluarga dan 9 responden $(90,00 \%)$ mengaku belum berumah tangga.

Tempat lahir responden wilayah Banjar Hulu. Untuk mengetahui tempat lahir responden pertanyaan yang disajikan adalah:

Dimanakah tempat lahir Anda?

Dengan demikian, data yang berkaitan dengan tempat lahir responden dapat dilihat pada tabel 6 di bawah ini.

Tabel 6.

Tempat lahir responden $(\mathrm{N}=10)$

\begin{tabular}{|c|l|c|c|}
\hline No & \multicolumn{1}{|c|}{ Pendidikan } & F & $\%$ \\
\hline 1 & Di Banjar Hulu & 9 & $90,00 \%$ \\
\hline 2 & Tidak di Banjar Hulu & 1 & $10,00 \%$ \\
\hline & Jumlah & 10 & $100,00 \%$ \\
\hline
\end{tabular}

Tabel 7.

Penguasaan terhadap bahasa Banjar Hulu ( $\mathrm{N}=10)$

\begin{tabular}{|c|l|c|c|}
\hline No & \multicolumn{1}{|c|}{ Penguasaan } & $\mathrm{F}$ & $\%$ \\
\hline 1 & Bisa & 8 & $80,00 \%$ \\
\hline 2 & Sedikit-sedikit & 2 & $20,00 \%$ \\
\hline 3 & Tidak Bisa & 0 & $0,00 \%$ \\
\hline & Jumlah & 10 & $100,00 \%$ \\
\hline
\end{tabular}

Data dari tabel 7 di atas menunjukkan bahwa mayoritas responden dapat berbahasa Banjar Hulu dengan baik walaupun ada kelompok etnik lain yang mendiami wilayah Banjar Hulu yang ditunjukkan dengan frekuensi penguasaan bahasa Banjar Hulu yang masih tinggi, yakni $(80,00 \%)$ responden bisa berbahasa Banjar Hulu.

Selanjutnya, dalam hal hubungan intrakelompok, dari 10 responden yang mengaku bahwa di lingkungan tempat tinggalnya banyak yang sesuku Banjar Hulu sebanyak 8 responden $(80,00 \%)$, yang mengaku banyak yang tinggal sesama suku Banjar Hulu, sebanyak 1 responden (10,00\%) yang mengaku agak banyak yang tinggal sesama suku Banjar Hulu, dan 1 responden $(10,00 \%)$ yang mengaku sedikit tinggal sesama suku Banjar Hulu. Data ini disajikan pada tabel 8 di bawah ini.

Tabel 8.

Banyaknya orang sesuku di lingkungan tempat tinggal Responden $(\mathrm{N}=10)$

\begin{tabular}{|c|l|c|c|}
\hline No & \multicolumn{1}{|c|}{ Banyaknya } & F & $\%$ \\
\hline 1 & Banyak & 8 & $80,00 \%$ \\
\hline 2 & Agak banyak & 1 & $10,00 \%$ \\
\hline 3 & Sedikit & 1 & $10,00 \%$ \\
\hline & Jumlah & 10 & $100,00 \%$ \\
\hline
\end{tabular}




\section{Pemertahanan Bahasa Banjar Hulu pada Kelompok Dewasa}

Analisis pemertahanan bahasa Banjar Hulu pada kelompok dewasa sama dengan analisis pada kelompok remaja. Pertanyaan-pertanyaan untuk memperoleh jawaban tentang penggunaan bahasa pada semua ranah sama dengan pertanyaanpertanyaan yang disajikan pada kelompok remaja.

Berdasarkan jumlah responden kelompok dewasa ini terdiri dari 5 dewasa wanita dan 5 dewasa laki-laki dan diperoleh jawaban tentang penggunaan bahasa Banjar Hulu responden pada ranah:

\section{Ranah Keluarga}

Di bawah ini akan disajikan tabel data penggunaan bahasa Banjar Hulu pada kelompok dewasa jika berbicara dengan Kakek.

Tabel 9.

Bahasa yang digunakan orang dewasa jika berbicara dengan kakek $(\mathrm{N}=10)$

\begin{tabular}{|c|l|c|c|}
\hline No & \multicolumn{1}{|c|}{ Bahasa } & F & $\%$ \\
\hline 1 & Banjar Hulu & 10 & $100 \%$ \\
\hline 2 & Daerah lain & 0 & $0,00 \%$ \\
\hline 3 & Indonesia & 0 & $0,00 \%$ \\
\hline 4 & Asing & 0 & $0,00 \%$ \\
\hline 5 & Blangko & 0 & $0,00 \%$ \\
\hline & Jumlah & 10 & $100 \%$ \\
\hline
\end{tabular}

Semua responden yang berjumlah 10 responden dewasa yang terlibat dalam penelitian ini memberikan jawaban bahwa mereka menggunakan bahasa Banjar Huluketika berbicara dengan kakek.Sama halnya berbicara dengan kakek, kelompok dewasa juga menunjukkan persentase yang sama 100\% (10 responden) menggunakan bahasa Banjar Huluketika berbicara dengan nenek. Hal ini ditunjukkan pada tabel 10 di bawah ini.

Tabel 10.

Bahasa yang digunakan orang dewasa jika berbicara dengan nenek $(\mathrm{N}=10)$

\begin{tabular}{|c|l|c|c|}
\hline No & \multicolumn{1}{|c|}{ Bahasa } & f & $\%$ \\
\hline 1 & Banjar Hulu & 10 & $100 \%$ \\
\hline 2 & Daerah lain & 0 & $0,00 \%$ \\
\hline 3 & Indonesia & 0 & $0,00 \%$ \\
\hline 4 & Asing & 0 & $0,00 \%$ \\
\hline 5 & Blangko & 0 & $0,00 \%$ \\
\hline & Jumlah & 10 & $100 \%$ \\
\hline
\end{tabular}

Selanjutnya, persentase penggunaan bahasa Banjar Hulu kelompok dewasa apabila berbicara dengan Ayah adalah sebanyak 100\% setara dengan 10 responden. Hal tersebut dapat dilihat pada tabel 11 berikut ini. 
Tabel 11.

Bahasa yang digunakan orang dewasa jika berbicara dengan Ayah $(\mathrm{N}=10)$

\begin{tabular}{|c|l|c|c|}
\hline No & \multicolumn{1}{|c|}{ Bahasa } & f & $\%$ \\
\hline 1 & Banjar Hulu & 10 & $100 \%$ \\
\hline 2 & Daerah lain & 0 & $0,00 \%$ \\
\hline 3 & Indonesia & 0 & $0,00 \%$ \\
\hline 4 & Asing & 0 & $0,00 \%$ \\
\hline 5 & Blangko & 0 & $0,00 \%$ \\
\hline & Jumlah & 10 & $100 \%$ \\
\hline
\end{tabular}

Sebanyak 10 responden (100.00\%) menggunakan bahasa Banjar Hulu jika berkomunikasi dengan Ibu. Hal ini dapat dilihat pada tabel 12 berikut ini.

Tabel 12.

Bahasa yang digunakan orang dewasa jika berbicara dengan Ibu $(\mathrm{N}=10)$

\begin{tabular}{|c|l|c|c|}
\hline No & \multicolumn{1}{|c|}{ Bahasa } & f & $\%$ \\
\hline 1 & Banjar Hulu & 10 & $100,00 \%$ \\
\hline 2 & Daerah lain & 0 & $00,00 \%$ \\
\hline 3 & Indonesia & 0 & $0,00 \%$ \\
\hline & Jumlah & 10 & $100,00 \%$ \\
\hline
\end{tabular}

Hal yang sama juga ditemukan jika berbicara dengan saudara persentase kelompok dewasa sebanyak $100,00 \%$ atau 10 responden mengaku menggunakan bahasa Banjar Hulu jika berkomunikasi. Hal ini dapat dilihat pada tabel 13 berikut ini.

Tabel13.

Bahasa yang digunakan orang dewasa jika berbicara dengan Saudara $(\mathrm{N}=10)$

\begin{tabular}{|c|l|c|c|}
\hline No & \multicolumn{1}{|c|}{ Bahasa } & f & $\%$ \\
\hline 1 & Banjar Hulu & 10 & $100,00 \%$ \\
\hline 2 & Daerah lain & 0 & $00,00 \%$ \\
\hline 3 & Indonesia & 0 & $0,00 \%$ \\
\hline 4 & Asing & 0 & $0,00 \%$ \\
\hline & Jumlah & 10 & $100,00 \%$ \\
\hline
\end{tabular}

Selanjutnya, dalam ranah keluarga 1 dari 10 responden kelompok dewasa sudah menikah1 responden $(10,00 \%)$ menggunakan bahasa Banjar Hulu dalam berkomunikasi dengan Suaminya,sedangkan 9 responden atau 90,00\% tidak mengisi pilihan atau blanko karena responden belum menikah. Hal ini dapat dilihat pada tabel 14 berikut ini.

Tabel 14.

Bahasa yang digunakan orang dewasa jika berbicara dengan Suami $(\mathrm{N}=10)$

\begin{tabular}{|c|l|c|c|}
\hline No & \multicolumn{1}{|c|}{ Bahasa } & f & $\%$ \\
\hline 1 & Banjar Hulu & 1 & $10,00 \%$ \\
\hline 2 & Daerah lain & 0 & $00,00 \%$ \\
\hline 3 & Indonesia & 0 & $0,00 \%$ \\
\hline
\end{tabular}




\begin{tabular}{|c|l|c|c|}
\hline 4 & Blangko & 9 & $90,00 \%$ \\
\hline & Jumlah & 10 & $100 \%$ \\
\hline
\end{tabular}

Pada kelompok dewasa dari 10 responden yang sudah menikah hanya 1 responden yang sudah mempunyai anak, dalam berkomunikasi dengan anak sebanyak 1 responden $(10,00 \%)$ menggunakan bahasa Banjar Hulu. Hal tersebut dapat dilihat pada tabel 15 berikut ini.

Tabel 15.

Bahasa yang digunakan orang dewasa jika berbicara dengan anak

\begin{tabular}{|c|l|c|c|}
\hline No & \multicolumn{1}{|c|}{ Bahasa } & f & $\%$ \\
\hline 1 & Banjar Hulu & 1 & $10,00 \%$ \\
\hline 2 & Daerah lain & 0 & $0,00 \%$ \\
\hline 3 & Indonesia & 0 & $0,00 \%$ \\
\hline 4 & Asing & 0 & $0,00 \%$ \\
\hline & Blangko & 9 & $90,00 \%$ \\
\hline & Jumlah & 10 & $100 \%$ \\
\hline
\end{tabular}

Berdasarkan data-data di atas penggunaan bahasa Banjar Hulu kelompok dewasa pada ranah keluarga dapat diuraikan sebagai berikut,

a. Persentase penggunaan bahasa Banjar Hulu kelompok dewasa apabila berbicara dengan kakek, nenek, ayah, ibu, dan saudara adalah sebanyak $100,00 \%$ atau 10 responden.

b. 1 dari $10(10,00 \%)$ responden kelompok dewasa yang sudah menikah dan menggunakan bahasa Banjar Hulu dalam berkomunikasi dengan Suaminya.

c. Pada kelompok dewasa dari 10 responden yang sudah menikah hanya 1 responden yang sudah mempunyai anak, dalam berkomunikasi dengan anak responden $(10,00 \%)$ menggunakan bahasa Banjar Hulu.

Maka secara akumulatif dapat diambil kesimpulan penggunaan bahasa Banjar Hulu pada kelompok dewasa di ranah keluarga adalah $100,00 \%+100,00 \%$ $+100,00 \%+100,00 \%+100,00 \%+10,00 \%+10,00 \%=520,00 \%: 7=74,28 \%$. Dengan demikian dapat disimpulkan bahwa pemakaian bahasa Banjar Hulu pada ranah keluarga masih dipertahankan oleh etnis Banjar Hulu di Banjarmasin.

\section{Ranah Pergaulan}

Data-data penggunaan bahasa kelompok dewasa pada ranah pergaulan dapat dilihat pada tabel-tabel berikut ini.

Tabel 16.

Bahasa yang digunakan orang dewasa jika berbicara dengan teman sesuku $(\mathrm{N}=10)$

\begin{tabular}{|c|l|c|c|}
\hline No & \multicolumn{1}{|c|}{ Bahasa } & F & $\%$ \\
\hline 1 & Banjar Hulu & 10 & $100 \%$ \\
\hline 2 & Daerah lain & 0 & $0,00 \%$ \\
\hline 3 & Indonesia & 0 & $0,00 \%$ \\
\hline 4 & Asing & 0 & $0,00 \%$ \\
\hline
\end{tabular}




\begin{tabular}{|l|l|l|}
\hline Jumlah & 10 & $100 \%$ \\
\hline
\end{tabular}

Tabel 17.

Bahasa yang digunakan orang dewasa jika berbicara dengan teman tidak sesuku $(\mathrm{N}=10)$

\begin{tabular}{|c|l|c|c|}
\hline No & \multicolumn{1}{|c|}{ Bahasa } & f & $\%$ \\
\hline 1 & Banjar Hulu & 3 & $30,00 \%$ \\
\hline 2 & Daerah lain & 1 & $10,00 \%$ \\
\hline 3 & Indonesia & 6 & $60,00 \%$ \\
\hline 4 & Asing & 0 & $0,00 \%$ \\
\hline & Jumlah & 10 & $100 \%$ \\
\hline
\end{tabular}

Tabel 18.

Orang dewasa jika berbicara dengan yang lebih tua dan sesuku $(\mathrm{N}=10)$

\begin{tabular}{|c|l|c|c|}
\hline No & \multicolumn{1}{|c|}{ Bahasa } & $\mathrm{F}$ & $\%$ \\
\hline 1 & Banjar Hulu & 9 & $90,00 \%$ \\
\hline 2 & Daerah lain & 1 & $10,00 \%$ \\
\hline 3 & Indonesia & 0 & $0,00 \%$ \\
\hline 4 & Asing & 0 & $0,00 \%$ \\
\hline & Jumlah & 10 & $100 \%$ \\
\hline
\end{tabular}

Tabel 19.

Orang dewasa jika berbicara dengan yang lebih tua dan tidak sesuku $(\mathrm{N}=10)$

\begin{tabular}{|c|l|c|c|}
\hline No & \multicolumn{1}{|c|}{ Bahasa } & f & $\%$ \\
\hline 1 & Banjar Hulu & 3 & $30,00 \%$ \\
\hline 2 & Daerah lain & 0 & $0,00 \%$ \\
\hline 3 & Indonesia & 7 & $70,00 \%$ \\
\hline 4 & Asing & 0 & $0,00 \%$ \\
\hline & Jumlah & 10 & $100 \%$ \\
\hline
\end{tabular}

Tabel 20.

Orang dewasa jika berbicara dengan yang lebih muda dan sesuku $(\mathrm{N}=10)$

\begin{tabular}{|c|l|c|c|}
\hline No & \multicolumn{1}{|c|}{ Bahasa } & F & $\%$ \\
\hline 1 & Banjar Hulu & 8 & $80,00 \%$ \\
\hline 2 & Daerah lain & 0 & $0,00 \%$ \\
\hline 3 & Indonesia & 2 & $20,00 \%$ \\
\hline 4 & Asing & 0 & $0,00 \%$ \\
\hline & Jumlah & 10 & $100,00 \%$ \\
\hline
\end{tabular}

Tabel 21.

Orang dewasa jika berbicara dengan yang lebih muda dan tidak sesuku $(\mathrm{N}=10)$

\begin{tabular}{|c|l|c|c|}
\hline No & \multicolumn{1}{|c|}{ Bahasa } & f & $\%$ \\
\hline 1 & Banjar Hulu & 3 & $30,00 \%$ \\
\hline 2 & Daerah lain & 0 & $0,00 \%$ \\
\hline 3 & Indonesia & 7 & $70,00 \%$ \\
\hline 4 & Asing & 0 & $0,00 \%$ \\
\hline & Jumlah & 0 & $100,00 \%$ \\
\hline
\end{tabular}


Berdasarkan tabel 16 terlihat persentase penggunaan bahasa Banjar Hulu pada kelompok dewasa dengan interlokutor teman sesuku sebanyak $100,00 \%$ atau 10 responden menggunakan bahasa Banjar Hulu. Tabel 17 menunjukkan sebanyak $60,00 \%$ atau 6 responden menggunakan bahasa Indonesia, sebanyak 3 responden atau sebanyak 30,00\% mengunakan bahasa Banjar Hulu, dan 1 responden $(10,00 \%)$ menggunakan bahasa daerah lain jika berkomunikasi dengan teman yang tidak sesuku.

Responden kelompok dewasa jika berbicara dengan yang lebih tua dan sesuku lebih banyak menggunakan bahasa Banjar Hulu dalam berkomunikasi hal ini dapat dilihat pada tabel 18 sebanyak 9 responden $(90,00 \%)$ dan 1 responden $(10,00 \%)$ menggunakan bahasa daerah lain, sedangkan jika berbicara dengan yang lebih tua dan tidak sesuku 3 responden $(30,00 \%)$ tetap menggunakan bahasa Banjar Hulu dan 7 responden $(70,00 \%)$ bahasa Indonesia dalam berkomunikasi.

Kelompok dewasa jika berbicara dengan orang yang lebih muda dan sesuku lebih dominan menggunakan Bahasa Banjar Hulu seperti pada tabel 20 yaitu sebanyak 8 responden atau $80,00 \%$ dan sebanyak 2 responden atau 20,00\% menggunakan bahasa Indonesia. Tabel 21 menunjukkan persentase penggunaan bahasa kelompok dewasa jika berbicara dengan orang yang lebih muda dan tidak sesuku, pada tabel tersebut 7 responden $(70,00 \%)$ menggunakan bahasa Indonesia dan sebanyak 3 responden (30,00\%) menggunakan bahasa Banjar Hulu.

Secara umum penggunaan bahasa Banjar Hulu pada ranah pergaulan di kelompok dewasa jika berbicara dengan sesuku adalah 100,00\% $+90,00 \%+$ $80,00 \%: 3=270,00 \%: 3=90,00 \%$ menggunakan bahasa Banjar Hulu, sedangkan bahasa Indonesia digunakan pada ranah pergaulan kelompok dewasa jika berbicara dengan yang tidak sesuku adalah $60,00 \%+70,00 \%+70,00 \%: 3=$ $200,00 \%: 3=66,67 \%$.

\section{Ranah Pekerjaan}

Tabel 22.

Orang dewasa jika berbicara dengan teman sesuku di ranah pekerjaan $(\mathrm{N}=10)$

\begin{tabular}{|c|l|c|c|}
\hline No & \multicolumn{1}{|c|}{ Bahasa } & $\mathrm{F}$ & $\%$ \\
\hline 1 & Banjar Hulu & 9 & $90,00 \%$ \\
\hline 2 & Daerah lain & 1 & $10,00 \%$ \\
\hline 3 & Indonesia & 0 & $0,00 \%$ \\
\hline 4 & Asing & 0 & $0,00 \%$ \\
\hline & Blangko & 0 & $0,00 \%$ \\
\hline & Jumlah & 10 & $100,00 \%$ \\
\hline
\end{tabular}

Pada ranah pekerjaan dari 10 responden hanya 2 responden yang sudah berkerja. Persentase pengunaan bahasa Banjar Hulu pada ranah pekerjaan sebanyak 90,00\% atau 9 responden menggunakan Bahasa Banjar Hulu dan 1 responden atau $10,00 \%$ menggunakan bahasa daerah lain jika berbicara dengan teman sesuku di ranah pekerjaan. 
Tabel 23.

Orang dewasa jika berbicara dengan teman tidak sesuku di ranah pekerjaan

$(\mathrm{N}=10)$

\begin{tabular}{|c|l|c|c|}
\hline No & \multicolumn{1}{|c|}{ Bahasa } & F & $\%$ \\
\hline 1 & Banjar Hulu & 2 & $20,00 \%$ \\
\hline 2 & Daerah lain & 0 & $0,00 \%$ \\
\hline 3 & Indonesia & 8 & $80,00 \%$ \\
\hline 4 & Asing & 0 & $0,00 \%$ \\
\hline & Blangko & 0 & $0,00 \%$ \\
\hline & Jumlah & 10 & $100,00 \%$ \\
\hline
\end{tabular}

Pada ranah pekerjaan dari 10 responden hanya 2 responden yang sudah berkerja. Persentase pengunaan bahasa Banjar Hulu pada ranah pekerjaan sebanyak $20,00 \%$ atau 2 responden dan 8 responden atau 80,00\% menggunakan bahasa Indonesia jika berbicara dengan teman tidak sesuku di ranah pekerjaan.

\section{Ranah Pendidikan}

Semua responden berjumlah 10 atau $100,00 \%$ yang berstatusmahasiswa sebanyak 7 responden dan sebanyak 3 responden kelompok dewasa menggunakan bahasa Banjar Hulu dalam berkomunikasi dengan teman yang sesuku di sekolah hal ini ditunjukkan pada tabel 45 berikut ini.

Tabel 24.

Orang dewasa jika berbicara dengan teman sesuku di Sekolah $(\mathrm{N}=10)$

\begin{tabular}{|c|l|c|c|}
\hline No & \multicolumn{1}{|c|}{ Bahasa } & f & $\%$ \\
\hline 1 & Banjar Hulu & 10 & $100,00 \%$ \\
\hline 2 & Daerah lain & 0 & $0,00 \%$ \\
\hline 3 & Indonesia & 0 & $0,00 \%$ \\
\hline 4 & Asing & 0 & $0,00 \%$ \\
\hline 5 & Blangko & 0 & $0,00 \%$ \\
\hline & Jumlah & 10 & $100,00 \%$ \\
\hline \multicolumn{2}{|l}{} \\
\hline
\end{tabular}

Tabel 25.

Orang dewasa jika berbicara dengan teman tidak sesuku di Sekolah ( $\mathrm{N}=10)$

\begin{tabular}{|c|l|c|c|}
\hline No & \multicolumn{1}{|c|}{ Bahasa } & f & $\%$ \\
\hline 1 & Banjar Hulu & 5 & $50,00 \%$ \\
\hline 2 & Daerah lain & 2 & $20,00 \%$ \\
\hline 3 & Indonesia & 3 & $30,00 \%$ \\
\hline 4 & Asing & 0 & $0,00 \%$ \\
\hline 5 & Blangko & 0 & $0,00 \%$ \\
\hline & Jumlah & 10 & $100,00 \%$ \\
\hline
\end{tabular}

Pada ranah pendidikan penggunaan bahasa Banjar Huludari 10 responden 5 responden $(50,00 \%)$ yang menggunakan bahasa Banjar Hulu untuk berkomunikasi dengan yang tidak sesuku, 2 responden $(20,00 \%)$ menggunakan bahasa lainnya, 
dan sebanyak 3 responden (30,00\%) yang menggunakan Bahasa Indonesia jika berbicara dengan teman sekolah yang tidak sesuku.

Berdasarkan analisis data di atas penggunaan bahasa Banjar Hulu kelompok dewasa pada ranah keluarga, ranah pergaulan, ranah pekerjaan, dan ranah pendidikan dapat dijabarkan sebagai berikut,

a. Pada ranah keluarga sebanyak $100,00 \%$ atau sama dengan 10 responden kelompok dewasa masih menggunakan bahasa Banjar Hulu.

b. Ranah pergaulan persentase pemakaian bahasa Banjar Hulu pada kelompok dewasa adalah $90,00 \%$ atau sebanyak 9 responden, sedangkan sebanyak $10,00 \%$ atau sekitar 1 responden menggunakan bahasa daerah lainnya jika berbicara dengan yang sesuku.

c. Pada ranah pekerjaan tidak semua responden memberikan jawaban, karena dari 10 responden hanya 2 responden yang sudah berkerja. Persentase pengunaan bahasa Banjar Hulu pada ranah pekerjaan sebanyak $90,00 \%$ atau sebanyak 9 responden, sedangkan sebanyak $10,00 \%$ atau sekitar 1 responden menggunakan bahasa daerah lainnyadalam berkomunikasi.

d. Dari 10 responden ada responden yang masih berstatus sebagai mahasiswa sebanyak 70,00\% atau 7 responden kelompok dewasa menggunakan bahasa Banjar Hulu dan penggunaan bahasa daerah lain juga menunjukkan jumlah yang sama dalam berkomunikasi.

Dengan demikian untuk mendapatkan jumlah rata-rata dan persentase penggunaan bahasa Banjar Hulu, bahasa daerah lain dan bahasa Indonesia pada kelompok dewasa, jumlah seluruh persentase dibagi banyaknya ranah.

Rumus yang digunakan adalah $\mathbf{X}=\mathbf{\Sigma} \mathbf{X}: \mathbf{n}$

$$
\begin{array}{ll}
\mathbf{\Sigma} \mathbf{X} & =\text { jumlah seluruh persentase pada semua ranah } \\
\mathbf{n} & =\text { banyaknya ranah } \\
\mathbf{X} & =\text { rata-rata }
\end{array}
$$

1. Jumlah persentase dan responden pengguna bahasa Banjar Hulu pada kelompok dewasa adalah: $(100,00 \%+90,00 \%+90,00 \%+50,00 \%=330,00 \%$ : $4=82,50 \%) 82,50 \times 10=8$ responden.

2. Jumlah persentase dan responden pengguna bahasa daerah lain pada kelompok dewasa adalah: $(0,00 \%+0,00 \%+10,00 \%+20,00 \%=30,00 \%: 4=$ $7,50 \%) 7,50 \% \times 10=7$ responden.

3. Jumlah persentase dan responden pengguna bahasa Indonesia pada kelompok dewasa: $(0,00 \%+0,00 \%+0,00 \%+30,00 \%=30,00 \%: 7=4,28 \%) 4,28 \% \mathrm{x}$ $10=4$ responden.

Untuk memudahkan pembacaan uraian data di atas dapat dilihat pada tabel di bawah ini. 
Tabel 26.

Kesimpulan penggunaan bahasa pada kelompok dewasa

Bahasa yang digunakan Jumlah responden Persentase

$\begin{array}{lll}\text { Bahasa Banjar Hulu } & \mathbf{8} & \mathbf{8 2 , 5 0 \%} \\ \text { Bahasa daerah lainnya } & \mathbf{7} & \mathbf{7 , 5 0 \%} \\ \text { Bahasa Indonesia } & \mathbf{4} & \mathbf{4 , 2 8 \%}\end{array}$

Diagram bulat penggunaan bahasa Banjar Hulu pada kelompok dewasa.

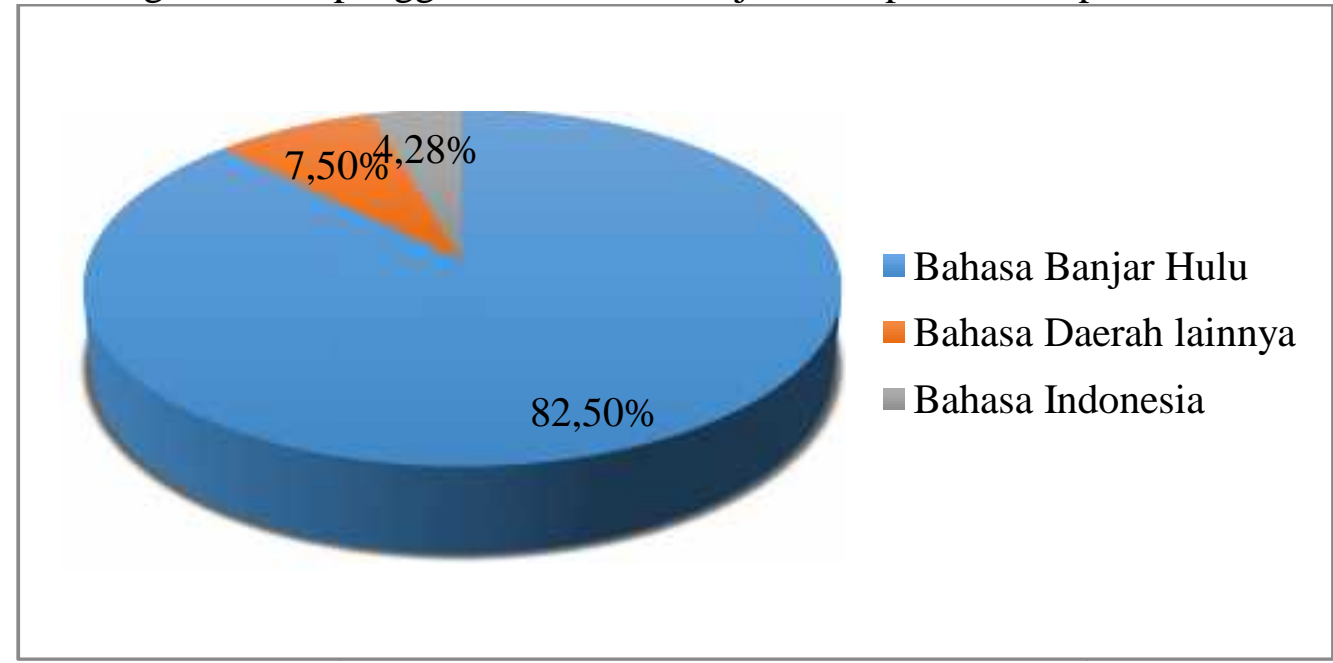

Keterangan :

1. Persentase penggunaan bahasa Banjar Hulu 0,00\% - 50,00\% dapat diartikan bahasa Banjar Hulu tidak bertahan.

2. Persentase penggunaan bahasa Banjar Hulu 50,00\% - 100,00\% dapat diartikan bahasa Banjar Hulu bertahan.

Berdasarkan data pada tabel di atas dapat diinterpretasikan bahwa pemertahanan bahasa Banjar Hulu pada kelompok usia dewasa masih terlaksana. Hal ini ditunjukkan persentase penggunaan bahasa Banjar Hulu pada kelompok dewasa masih bertahan yakni $82,50 \%$ atau jika diambil berdasarkan banyaknya responden adalah sebanyak 8 responden. Dikatakan bertahan karena lebih dari $50,00 \%$ responden kelompok dewasa menggunakan bahasa Banjar Hulu dalam berkomunikasi dengan sesukunya.

\section{SIMPULAN}

Sebagai bahasa ibu atau bahasa pertama, bahasa Banjar Hulu digunakan pada keempat ranah yaitu ranah keluarga, ranah pergaulan, ranah pekerjaan, dan ranah pendidikan.Secara keseluruhan kemampuan responden dalam berbahasa Banjar Hulu cukup tinggi. Hal ini dipengaruhi oleh beberapa faktor sebagai berikut. Pertama, di lingkungan tempat tinggal responden masih banyak yang sesuku Banjar Hulu. Kedua,orang tua responden baik Ayah atau Ibu berasal dari suku Banjar Hulu. Ketigaloyalitas bahasa responden cukup tinggi.

Sesuai dengan tujuan yang hendak dicapai penelitian ini, yakni untuk mengetahui tingkat pemertahanan bahasa Banjar Hulu di wilayah Banjarmasin. 
Maka, berdasarkan hasil dan pembahasan dapat ditarik kesimpulan sebagai berikut.

a. Pada ranah keluarga semua responden kelompok dewasa masih menggunakan bahasa Banjar Hulu.

b. Pada ranah pergaulan 9 responden menggunakan bahasa Banjar Hulu dan 1 responden menggunakan bahasa daerah lainnya jika berbicara dengan yang sesuku.

c. Pada ranah pekerjaan bahasa Banjar Huludigunakan 9 responden, sedangkan 1 responden menggunakan bahasa daerah lainnyadalam berkomunikasi.

d. Dari 10 responden ada responden yang masih berstatus sebagai mahasiswa 7 responden menggunakan bahasa Banjar Hulu dan sisanya menggunakan bahasa daerah lain dalam berkomunikasi.

\section{SARAN}

Penelitian ini hanya berkaitan tentang penggunaan bahasa Banjar Hulu pada ranah keluarga, ranah pergaulan, ranah pekerjaan, dan ranah pendidikan. Oleh karena itu, perlu penelitian lanjutan yang lebih lengkap dengan sampel yang lebih besar dan variabel yang beragam.

Hasil penelitian ini menunjukkan bahwa penggunaan bahasa Banjar Hulu pada semua ranah cenderung positif. Oleh karena itu, agar bahasa Banjar Hulu tetap bertahan perlu melibatkan unsur-unsur pemerintahan seperti Pemerintahan Kota Banjarmasin, organisasi masyarakat, organisasi kemahasiswaan, pakar linguistik, tenaga pengajar, dan lembaga yang berwenang dalam hal pengembangan bahasa Banjar Hulu.

\section{DAFTAR PUSTAKA}

Astar, Hidayatullah dan Syahidin Badru. 2003. Pemertahanan bahasa Cina di Jakarta. Jakarta: Pusat Bahasa.

Chaer, Abdul dan Leoni Agustina. 2010. Sosiolunguistik Perkenalan Awal. Jakarta: Rineka Cipta.

Damanik, Ramlan. 2009. Tesis: Pemertahanan Bahasa Simalungun di Kabupaten Simalungun. Medan: USU.

Gunarwan, Asim. 2002. Pedoman Penelitian Pemakaian Bahasa. Jakarta: Pusat Bahasa.

Koentjaraningrat. 1993. Metode-metode Penelitian Masyarakat. Jakarta: Gramedia.

Mahsun, M.S. 2007. Metode Penelitian Bahasa. Jakarta: PT Raja Grafindo Persada. 
Rafiek, Muhammad. 2007. Sosiologi Bahasa: Pengantar Dasar Sosiolunguistik. Banjarmasin-Yogyakarta: FKIP Unlam-LkiS.

Saukah, Ali dkk. 2007. Pedoman Penulisan Karya Ilmiah. Surabaya: Universitas Negeri Malang.

Siregar, D. Syahrial Isa dan Chairul Husni. 1998. Pemertahanan Bahasa dan Sikap Bahasa. Jakarta: Pusat pembinaan dan pengembangan bahasa.

Sugiyono. 2008. Metode Penelitian Kuantitatif, Kualitatif \& $R \& D$. Bandung : Alfabeta.

Suhardi, Basuki. 2009. Pedoman Penelitian Sosiolinguistik. Jakarta: Pusat Bahasa Departemen Pendidikan Nasional.

Sumarsono. 2007. Sosiolinguistik. Yogyakarta: Sabda dan Pustaka Pelajar.

Yuliawati, Susi. 2008. Situasi Kebahasaan di Wilayah PangAndaran: Suatu Kajian Sosiolinguistik tentang Pergeseran dan Pemertahanan Bahasa. Bandung: Universitas Padjadjaran. 